\title{
Extending the research agenda on (ethical) coaching and mentoring in education: embracing mutuality and prioritising well-being
}

\author{
Andrew J. Hobson* = Christian van Nieuwerburgh\# \\ *School of Education, University of Brighton, England \\ \#Royal College of Surgeons in Ireland (RCSI), Ireland
}

\section{Structured abstract}

Purpose: The purpose of this paper is to present a review of the evidence base on coaching and mentoring in education, to provide a commentary on literature published in the first 10 volumes of the International Journal of Mentoring and Coaching in Education (IJMCE) in particular, and to offer some directions for future research in the field.

Design/methodology/approach: This position paper draws on our knowledge of the extant literature on coaching and mentoring in education, our own research in the field, and our perspectives as editors of coaching and mentoring journals.

Findings: Among the outcomes of our review and commentary, we observe that coaching and mentoring research conducted to date appears to occupy two separate fields, and studies published in one field frequently fail to draw on relevant literature from the other or recognise the overlap between them. We highlight a number of additional limitations of the evidence base on coaching and mentoring in education and offer some potential means of addressing these.

Originality/value: The paper offers an original reflection on current research into coaching and mentoring in education. It is intended that the paper will inform the design and publication of future studies in this area to strengthen the evidence base and, in turn, inform improvements to coaching and mentoring practice. In particular, we hope to encourage the ethical deployment of coaching and mentoring which enhances rather than inhibits the well-being of all participants, while realising other positive outcomes. 
Key words: Ethical coaching and mentoring, well-being, research agenda, ethical co-authorship

\section{Introduction}

In this paper, we (the authors) share some of our reflections on the current evidence base on coaching and mentoring in education. We reflect in particular, though not exclusively, on research published in the first 10 volumes of the International Journal of Mentoring and Coaching in Education (IJMCE) - the only peer-reviewed journal that specifically focuses on coaching and mentoring in the field of education - since its inception in 2012 to the end of 2021. We identify some advances in coaching and mentoring research conducted to date within the field of education, while highlighting some remaining deficiencies in the evidence base and proposing a number of potentially fruitful avenues for further research. Among the latter, we present a case for prioritising research into how coaching and mentoring can support the wellbeing of educators, students and other professionals across the education sector. Shortly, we provide what we consider to be important contextual information regarding researcher/author positionality. First, though, we highlight our shared commitment to ethical co-authorship, reflected in our use of Hobson = van Nieuwerburgh as opposed to Hobson and van Nieuwerburgh, or vice versa, as the correct citation for this paper. We explain our rationale for this, following international mentoring authorities Frances Kochan and Carol Mullen (Kochan = Mullen, 2001), in the paper's postscript.

\section{Researcher positionality}

Apart from our shared commitment to ethical authorship, which reflects a broader commitment to social justice, we also share commitments to coaching and mentoring (in education, health and further afield), mental health and well-being, and rigorous and impactful research in relation to coaching, mentoring and well-being. We consider rigorous research, whether employing quantitative, qualitative or mixed-methods approaches, to include that which has high degrees of trustworthiness, incorporating credibility, dependability and confirmability (Guba and Lincoln, 1994). In addition, we consider catalytic authenticity (Guba and Lincoln, 1994) to be of particular importance in our desire that our own and others' research will provide an impetus for change which will positively impact education, health, 
individuals and society. We favour a theoretically and methodologically eclectic approach in which the selection of theoretical frameworks and methods of data generation and data analysis are determined by our consideration of their fitness for purpose in relation to the research aims or questions of specific studies, while our own research aims and questions tend to be at least partly shaped by our desire for research findings to have potential applicability to real-life situations. Our positions on these and other matters are inevitably influenced by our prior experiences, the more pertinent of which we briefly outline below.

I, Andy, first experienced formal mentoring as a trainee teacher (and mentee) in England in the late 1980s and went on to become a mentor to newly qualified teachers, a role in which, for various reasons (not least the lack of any mentor training), I did not excel and of which I am not proud. I went on to study mentoring (as a key component of initial teacher preparation) for my PhD between 1998 and 2001, and mentoring has been central to my research endeavours since then. I became editor-in-chief of IJMCE in 2012. Over the last decade or so, I have become increasingly interested in the impact of mentoring, coaching and other educational developments on educators' well-being. I put this down to several considerations. One is an early and ongoing affinity with John Stuart Mill's classic text, Utilitarianism and its central though not uncontested or unproblematic tenet (the Greatest Happiness Principle) that "actions are right in proportion as they tend to promote happiness, wrong as they tend to produce the reverse of happiness" (Mill, 1861/1962, p. 257). A second influence on my growing interest in well-being is an increased awareness and felt experience, through both my research and my employment in higher education institutions, of factors that both positively and negatively impact employees' (including my own) well-being. My concern to enhance and to avert or mitigate impediments to educators' well-being was instrumental in my development of the ONSIDE Mentoring Framework (Hobson, 2016, 2020, 2021).

I, Christian, am passionate about the role of education in empowering people and providing them with the skills and knowledge to live better lives because of my childhood experiences in Beirut, Lebanon. Despite the civil war in the country, I received a good education which gave 
me choices, including the opportunity to study at the American University of Beirut and then pursue a PhD at the Shakespeare Institute of the University of Birmingham in England (19972007). While pursuing my studies, I worked for the education department of Warwickshire County Council. In this role, I became increasingly curious about how educators could be supported to learn and develop in a way that was good for them and their students. During this time, I trained to become an executive coach through the (then) West Midlands Coaching Pool. In 2011, I joined the School of Psychology at the University of East London to teach a module on coaching in education. I published my first edited book, Coaching in Education: Getting Better Results for Students, Educators and Parents, in 2012. In 2014, I joined Growth Coaching International, a global, Australia-based coach training provider for the education sector. My growing interest in the importance of well-being led to a move to the Royal College of Surgeons in Ireland (RCSI) in September 2021, where I work with colleagues at the Centre for Positive Psychology and Health to set up a Master of Science in Positive Health Coaching. I was editorin-chief of Coaching: An International Journal of Theory, Research and Practice (2016-2019) and am currently a member of IJMCE's Editorial Advisory Board.

Having identified pertinent matters pertaining to researcher positionality, we now offer some critically reflective comments on the current evidence base relating to coaching and mentoring in education and present what we consider to be important features of a positive and impactful future research agenda for coaching and mentoring in education.

\section{Some means of enhancing the rigour of research on coaching and mentoring in education}

Shortly after IJMCE was established in 2012, Frances Kochan edited a 2013 special issue of the journal entitled 'Extending the Research Agenda on Mentoring in Education'. In her editorial, she noted that despite the growing body of research on mentoring in education in recent times, there were two major limitations of such research which researchers ought to address. The first was that much of what was written about mentoring in education had "been built upon or used citations from business, leadership, or other fields" such that "there does not appear to be a high quality, cohesive, easily accessible body of research available focused on the primary issues of mentoring theory and practice in education" (Kochan, 2013, p. 168). At the time, a 
similar critique could equally and legitimately have been made of the evidence base on coaching in education.

We consider that, in the intervening years since Kochan's (2013) critique, mentoring (and coaching) research has largely addressed this first limitation, not least through many excellent studies published in IJMCE which, ahead of this issue, has amassed 10 volumes, 37 issues and 206 individual articles. ${ }^{i}$ While some parts of the field are inevitably more mature than others (Allen and Eby, 2021), there is now a significant, specialised body of literature on coaching and mentoring (including coaching and mentoring theory and practice) in education.

\section{Scale, context and best evidence}

The second limitation of the evidence base on mentoring in education, for Kochan (2013), was that the research undertaken had been relatively small scale and "focused on single cases, states, countries, or other settings" (p. 168). Hence, as Mullen (2012) suggested, there was a need for more large-scale and international or global research. Progress has been made in this regard, too, with several relatively large-scale coaching and mentoring studies undertaken (e.g. Diller et al., 2021; Waaland, 2021), along with a growing number of comparative and international studies (e.g. Mena et al., 2020; Tonna et al., 2017). Nonetheless, this second limitation of the evidence base largely remains insofar as the vast majority of studies are confined to single states and countries, many report on single cases or programmes, and few interrogate the extent to which research findings are specific to or relatively common or applicable across different professional and geographical contexts. While "it seems likely that there are some attributes of mentoring that are valid across many programs and contexts" (Kochan, 2013, p. 169), we consider this latter limitation to represent a notable gap in the evidence base, which may constrain the realisation of positive impacts of coaching and mentoring in education in practice. We are especially aware of the risk of overgeneralising the findings of research studies that have been undertaken in Western, educated, industrialised, rich and democratic (WEIRD) countries (Henrick et al., 2010). A recent conference in the Middle East thus addressed the question of whether an "indigenous coaching psychology" was needed 
for the region (King et al., 2021). There is a particular need for further research into coaching and mentoring applications in educational settings in non-WEIRD contexts.

More broadly, we encourage coaching and mentoring researchers to be ambitious both in the design of their studies and in planning and developing publications from these. We consider ambitious studies to include those with challenging research questions and sophisticated research designs, which are likely to strengthen the field. They might include serious attempts to address one or more shortcomings in the evidence base - for example, generating and analysing rich datasets which cast light on the thorny issue of the potential transferability of findings across different kinds of context.

With respect to publication plans, we would suggest that researchers exercise caution in following some of the strategic approaches to "splitting" data from their studies that we have witnessed as journal editors, which academics/faculty are often advised to do to maximise the number of publications they might achieve from any given study. That is, where coaching and/or mentoring research helpfully includes (for example) data from both coaches/mentors and coachees/mentees, and/or both qualitative and quantitative data, and/or data from different contexts, researchers often submit manuscripts for possible publication which are informed by the analysis of only a partial dataset (e.g. mentor/coach data only, qualitative data alone, or analysis relating to a single context). While there is sometimes a legitimate rationale for such approaches, the discussion in submitted manuscripts would sometimes benefit from an alternative perspective or alternative evidence which could have been provided by reporting outcomes from the analysis of data that were used in or are being reserved for another publication. One possible consequence is that such submissions are more likely to be rejected. Another is that, if the submissions are accepted for publication, they are nonetheless not as strong as they might have been in terms of methodological rigour and, partly as a result, are likely to have relatively modest significance in terms of their "capacity to influence knowledge and scholarly thought, or the development and understanding of policy and/or practice" (Research Excellence Framework, 2019, p. 35). We thus urge coaching and mentoring 
researchers to provide their "best evidence" and draw on the analysis of any or all data which help to illuminate the specific focus of a particular paper or its research questions. In general, we consider that, as a community of coaching and mentoring scholars in a relatively young academic discipline, we would better serve the development of our field by focusing on the quality rather than the quantity of the research that we undertake and publish.

\section{Theoretical frameworks and interdisciplinary research}

Among other potential means of enhancing the evidence base on coaching and mentoring in education, we also encourage more studies which utilise and potentially enhance and extend appropriate theoretical frameworks (e.g. Diller et al., 2021; Dominguez and Hager, 2013; Waaland, 2021) and/or are interdisciplinary in nature. Both coaching and mentoring interventions are typically intended to foster personal and professional growth and to support people to be better at what they do. From this perspective, there is significant overlap with the study of positive psychology, for example, which focuses on "what makes individuals and communities flourish, rather than languish" (Boniwell and Tunariu, 2019, p. 2). Research into positive psychology has been surging in recent years, with the launch of numerous academic journals (e.g. Journal of Positive Psychology, International Journal of Applied Positive Psychology), and numerous studies have considered the use of positive psychology in educational settings (e.g. Ng and Vella-Brodrick, 2019; Proctor et al., 2011; Waters, 2017). We thus consider that there is much potential for greater integration and collaboration across the fields of coaching, mentoring and positive psychology (van Nieuwerburgh and Oades, 2017), while there are doubtless also substantial potential benefits of coaching and mentoring research which cross alternative inter- and transdisciplinary boundaries.

\section{Mentoring versus coaching: from separatism to mutuality?}

We are conscious that, in published accounts of their studies, many researchers provide explanations of differences between coaching and mentoring which do not sufficiently acknowledge the commonalities between them or the wide range of coaching and mentoring theories, models, frameworks and approaches that are employed and deployed globally. To give a much-used (and contested) explanation, coaching is often described as a relatively non- 
directive means of support, by which coachees are facilitated to arrive at their own solutions to issues they have chosen to focus upon; mentoring is often described, in contrast, as a relatively hierarchical and directive relationship in which mentees (or protégés) are provided with advice and "solutions" by more knowledgeable and/or experienced mentors (van Nieuwerburgh, 2012). Yet many approaches to mentoring eschew such an approach in favour of more empowering, less directive and individualised "developmental" approaches (Clutterbuck, 2004; Hobson, 2016; Lofthouse, 2020), while some coaching programmes are relatively hierarchical and directive (Salavert, 2015). In short, there is no neat distinction between coaching and mentoring, while some approaches to mentoring have as much in common with some approaches to coaching as they do with other approaches to mentoring, and vice versa. In addition, and to the extent that meaningful distinctions between coaching and mentoring remain valid, it is worth noting that the Global Framework for Coaching and Mentoring in Education (van Nieuwerburgh et al., 2019) recognises the mutuality of both approaches. The framework proposes that both coaching and mentoring can be used to enhance educational leadership, professional practice of educators and affiliated staff, student success and wellbeing, and relationships between educational institutions and their communities.

We are cognisant of the fact that, in situating their studies within the wider literature, authors of publications about mentoring more often than not cite previous studies of mentoring but not previous studies of coaching, and vice versa. We acknowledge that this applies to some of our own earlier work. Yet, considering the mutuality and commonalities between specific approaches to coaching and specific approaches to mentoring, it logically follows that scholars should draw on both coaching and mentoring research. In other words, mentoring studies which only draw on previous research into mentoring, and coaching studies which only utilise previous research into coaching, may lack rigour insofar as they are only partially situated in their relevant research contexts. For example, a mentoring article might focus on mentoring schemes which relate more closely to some coaching schemes considered in literature that is excluded from its literature review than to some of the mentoring schemes considered in literature that is included, and vice versa. 
We observe, in relation to the above point, that since the inception of IJMCE in 2012, only six of the 206 articles published ahead of this issue feature both coaching and mentoring in their titles (Hakro and Mathew, 2020; Hollweck, 2019; Jones, 2015; Rhodes and Fletcher, 2013; Salter, 2015; Tee Ng, 2012). We would therefore urge other coaching and mentoring researchers, as we urge ourselves, to retreat from our coaching and mentoring silos and embrace relevant coaching and mentoring research within the same studies. We consider that it might significantly strengthen the field if this were to change over the course of the next decade, and we hope this might encourage greater collaboration between researchers who previously considered themselves to inhabit quite different (coaching and mentoring) fields and who come to realise that their research interests actually have much in common. There is also an opportunity to capitalise on similarities between coaching and mentoring as conversational approaches to bringing about various positive impacts in educational settings. We recognise that educators, leaders of coaching and mentoring schemes, and senior leaders of educational institutions are generally less interested in "academic" debates about definitions than in research and theories that inform practices which have benefits for educators and learners.

The final limitation of the coaching and mentoring in education evidence base that we wish to highlight concerns the relatively minor explicit focus on coaching and mentoring participants' well-being which, we fear, reflects the absence of the promotion of well-being as an explicit goal of many coaching and mentoring programmes in education in the first place. We consider these matters in more detail in the final section of this paper below.

\section{Ethical coaching and mentoring: bringing well-being front and centre}

Until a 2018 call for submissions to an IJMCE special issue on mentoring, coaching and wellbeing in education bore fruit in Kutsyuruba and Godden's (2019) special issue, the well-being of participants in coaching and mentoring programmes had not been a major focus of manuscripts submitted to or published in this journal or others. In the seven years prior to the publication of the aforementioned IJMCE special issue, no articles featured well-being (or wellbeing) in their titles, only one (Castanheira, 2016) included well-being among its keywords, and only two 
(Castanheira, 2016; Hobson, 2016) included well-being in their definitions of mentoring, with none including the term in their definitions of coaching. During the same period, the titles and keywords of published articles frequently cited alternative aims and positive outcomes of coaching and mentoring processes, including "school reform", "quality in education", "teacher quality", "teacher promotion", "leadership development", "transformative leadership", "academic development", and "retention".

We are not suggesting that well-being has not been a concern for coaching and mentoring researchers. We acknowledge, for example, that many scholars (and IJMCE articles) have focused on considerations closely related to well-being, including "satisfaction" (e.g. Diller et al., 2021), "job satisfaction" (e.g. Lunsford et al., 2018), "coping” (e.g. Cowin et al., 2016; Wilson and Huynh, 2020), "trust" (e.g. D'Souza, 2014), “confidence” (e.g. Whipp and Pengelley, 2017), and "emotional intelligence" and "empathy" (e.g. Tschannen-Moran and Carter, 2016). In addition, in the wider literature, several studies (e.g. Barry et al., 2017; Green et al., 2013; Green et al., 2006; Short et al., 2010) have considered the impact of coaching on participants' well-being, while van Nieuwerburgh and Oades (2017) highlighted that coaching and positive psychology "have a shared focus on ... enhancing subjective wellbeing and supporting sustainable optimal functioning" (p. 100; cf. Burke, 2017). Furthermore, since the publication of Kutsyuruba and Godden's (2019) IJMCE special issue, six additional articles have been published in this journal which include an explicit focus on mentoring or coaching and well-being (Al Makhamreh and Stockley, 2020; Atad and Grant, 2021; Dreer, 2021; Gillett-Swan and GrantSmith, 2020; Wilson and Huynh, 2020; Winter et al., 2020), with another (Wilcoxen et al., 2020) focusing on mentoring and coaching and well-being.

On the whole, however, well-being has not been a substantive focus of the vast majority of research studies on coaching and mentoring in education. This may be because a desire to enhance well-being has not been a major driver behind the introduction and development of most coaching and mentoring programmes in education, although in recent years we have witnessed a growth of "third-generation coaching" which seeks to promote well-being as well 
as improved performance (Grant, 2017; Roche, 2019). In the current climate, two key questions emerge, for us, in this regard. They are:

1) To what extent and in what ways do coaching and mentoring positively impact the wellbeing of coachees, mentees, coaches and mentors, even where this is not a stated aim of specific programmes, and how are such positive impacts facilitated?

2) Are some positive impacts of coaching and mentoring schemes in education achieved at the expense of a negative impact on the well-being of some participants (coachees/mentees and/or coaches/mentors), and if so, why is this?

We consider the second question to be a serious matter of concern which requires immediate attention. We are aware of, and have witnessed, many instances of the misappropriation of coaching and mentoring - to the detriment of educators' well-being - for what has variously been termed the performativity or neoliberal agenda (Ball, 2003; Keddie et al., 2011) or the global education reform movement (GERM) (Sahlberg, 2010), characterised by the monitoring of and accountability for employee effectiveness or "performance". For example, charging school-based mentors to contribute to the formal assessment and summative evaluation of student teachers, and deploying remedial "teaching and learning coaches" as part of a deficit model of addressing the perceived underperformance of teachers in the English further education and skills sector, have detrimentally impacted mentees' and coachees' well-being, as well as impeding their professional learning and development (Hobson, 2016; Hobson and Maxwell, 2020; Hobson and Mclntyre, 2013). We hypothesise, more broadly, that some of the educational gains reported and championed by organisations and governments in recent years may have occurred to the detriment of the well-being of some of those responsible for bringing them about, not least school teachers and academics/faculty. To some extent, such situations may have arisen as a result of both workload intensification and a performativity regime in which some employees live in fear of losing their jobs if they are not judged to be performing to the standards expected of them. As we have personally witnessed, such fear has been heightened in recent austere times, by increasingly frequent, thinly veiled references to potential job cuts by senior leaders of educational institutions. 
More positively, we have also witnessed and reported (Hobson 2021; Lucey and van Nieuwerburgh, 2020; van Nieuwerburgh et al., 2020), as have others (e.g. Dreer, 2020; KáplárKodácsy and Dorner, 2020; Kutsyuruba and Godden, 2019), effective coaching and mentoring to be helpful means of mitigating detrimental impacts of the GERM on educators and other professionals. We thus call for the widespread adoption of ethical coaching and mentoring, by which we mean approaches to coaching and mentoring that achieve positive outcomes without causing harm or having a detrimental impact on the well-being of participants. We hope that the promotion of participants' well-being, and the well-being of those they love, live and work with, will be brought to the front and centre of both the aims and objectives of coaching and mentoring schemes, and the coaching and mentoring in education research agenda.

\section{Conclusion}

In this paper we have identified both recent enhancements to and remaining shortcomings of the evidence base on coaching and mentoring in education, and we have proposed several means of addressing the shortcomings. We have called, for example, for (1) studies which interrogate to what extent research findings are specific to or applicable across different professional and geographical contexts, (2) studies which are interdisciplinary and/or draw on appropriate theoretical frameworks, and (3) research which draws upon both coaching and mentoring literature that is relevant to its aims and scope. Beyond this, it is imperative, for us, that those responsible for leading coaching and mentoring programmes do so in an ethically responsible manner, notably by seeking to ensure that such programmes do not achieve positive impacts, such as advancing participants' learning, development and/or job-related performance, at the expense of the well-being of coachees, mentees, coaches or mentors. It is thus also imperative that coaching and mentoring research highlights any instances of this unintended outcome, while also identifying the conditions under which positive impacts of coaching and mentoring include the enhancement of participants' well-being. Finally, through our research and scholarly endeavours, we would hope to convince more individuals and leadership teams who are responsible for coaching and mentoring programmes within their organisations and districts that the promotion of participants' well-being is one among other laudable aspirations for such programmes. 
We should stress that we have not attempted in this paper to provide an exhaustive account of the limitations of the coaching and mentoring in education evidence base or a comprehensive account of potentially fruitful avenues for further research. Additional valuable suggestions for further research are provided elsewhere (e.g. Allen and Eby, 2021). Nonetheless, we look forward to discovering whether other coaching and mentoring researchers see merit in and seek to take up one or more of the challenges we have posed for our community of scholars. We also welcome any critiques which might facilitate optimal development of the evidence base and optimal impacts of ethical coaching and mentoring in education.

\section{Postscript: ethical co-authorship}

In the introduction to this paper, we noted our shared commitment to ethical co-authorship and that the correct citation for this paper is Hobson = van Nieuwerburgh rather than Hobson and van Nieuwerburgh or vice versa. Here we explain why this is the case.

During our time as academics, we have both become aware of limiting conventions and practices in relation to the authorship of journal articles and other types of publication. This has become more pronounced in our minds in light of recent movements for social justice. Apparent injustices have taken the form, for example, of senior academics appearing to "pull rank" and put their names first on multi-authored outputs to which one or more co-authors arguably made more substantive contributions. It should be unambiguous that the order of authorship relates directly to the relative contribution of each author. In saying this, we acknowledge that the question of the relative contributions of different authors and members of research teams is not always clear cut and is, to some extent, a matter of judgement. In general, we support the position laid out in the Ethical Guidelines for Educational Research of the British Educational Research Association (BERA, 2018), which holds that

The authorship of publications normally comprises a list of everyone who has made a substantive and identifiable contribution to the research being reported. ... Academic status or any other indicator of seniority does not determine first authorship. Rather, 
the order of authorship should reflect relative leadership and contributions made. Alternatively, co-authors may agree to a simple alphabetic listing of their names. Consensual agreement on authorship should be gained as early as possible in the writing process. (BERA, 2018, p. 34)

We deliberately write "in general" above because there is a remaining issue for outputs to which co-authors are considered to have made an equal contribution, as is the case with this paper. Here, we agree with Mullen and Kochan that the "masculinist" academic convention of authorship order, "which 'forces' authors who are equal contributors to a manuscript to default to last name alphabetical order", is "inherently unequal" (Mullen, 2021, p. 4). We therefore follow these authors (e.g. Kochan = Mullen, 2001) in, first, using an equal sign rather than "and" (or " $\&$ ") between our names to convey that we are fully co- or joint-authors, and second, switching the order of our names for alternative co-authored publications to which we make approximately equal contributions. We suggest that others might choose to do the same, and we hope that journals and publishers will respect and support their decisions and this practice.

\section{Acknowledgements}

We are grateful to Linda Searby (IJMCE Co-Editor), Pam Firth (IJMCE Associate Editor) and Soo Sturrock (University of Brighton) for their valuable feedback on earlier versions of this paper.

\section{References}

Al Makhamreh, M. and Stockley, D. (2020), "Mentorship and well-being: Examining doctoral students' lived experiences in doctoral supervision context", International Journal of Mentoring and Coaching in Education, Vol. 9 No. 1, pp. 1-20, doi: /10.1108/IJMCE-022019-0013.

Allen, T.D. and Eby, L.T. (2021), "The Art and Science of Mentoring", in Reames, E.H. and Searby, L.J. (Eds), The Art and Science of Mentoring: A Festschrift in Honor of Dr. Frances Kochan, Information Age Publishing, Charlotte, NC, pp. 15-22.

Atad, O.I. and Grant, A.M. (2021), "Evidence-based coaching as a supplement to traditional lectures: impact on undergraduates' goal attainment and measures of mental wellbeing", International Journal of Mentoring and Coaching in Education, Vol. 10 No. 3, pp. 249-266. doi: org/10.1108/JJMCE-05-2020-0024. 
Ball, S. J. (2003), "The teacher's soul and the terrors of performativity", Journal of Education Policy, Vol. 18, pp. 215-228.

Barry, M., Murphy, M., and O'Donovan, H. (2017), “Assessing the effectiveness of a cognitive behavioural group coaching intervention in reducing symptoms of depression among adolescent males in a school setting", International Coaching Psychology Review, Vol. 12 No. 2, pp. 101-109.

Boniwell, I. and Tunariu, A. (2019), Positive psychology: Theory, research and applications, $2^{\text {nd }}$ edn, Open University Press, London.

British Educational Research Association [BERA] (2018), Ethical Guidelines for Educational Research, fourth edition, London. https://www.bera.ac.uk/researchersresources/publications/ethical-guidelines-for-educational-research-2018 (Accessed 22 August 2021)

Burke, J. (2017), "Conceptual framework for a positive psychology coaching practice", The Coaching Psychologist, Vol. 14 No. 1, pp. 16-25.

Castanheira, P.S.P. (2016), “Mentoring for educators' professional learning and development: A meta-synthesis of IJMCE volumes 1-4", International Journal of Mentoring and Coaching in Education, Vol. 5 No. 4, pp. 334-346. doi: 10.1108/IJMCE-10-2015-0030

Clutterbuck, D.C. (2004), Everyone Needs a Mentor: Fostering Talent in Your Organisation, Chartered Institute of Personnel and Development, London.

Cowin, K.M., Gates, G.S. and Luckett, K. (2016), "The relevance and promise of relational mentoring for school leadership: a conversation", International Journal of Mentoring and Coaching in Education, Vol. 5 No. 3, pp. 187-202. https://doi.org/10.1108/IJMCE-032016-0034

D'Souza, L.A. (2014), "Bridging the gap for beginning teachers: researcher as mentor", International Journal of Mentoring and Coaching in Education, Vol. 3 No. 2, pp. 171-187. doi: 10.1108/IJMCE-07-2013-0039

Diller, S.J., Muehlberger, C., Braumandl, I. and Jonas, E. (2021), Supporting students with coaching or training depending on their basic psychological needs, International Journal of Mentoring and Coaching in Education, Vol. 10 No. 1, pp. 84-100. https://doi.org/10.1108/IJMCE-08-2020-0050

Dominguez, N. and Hager, M. (2013), Mentoring frameworks: synthesis and critique, International Journal of Mentoring and Coaching in Education, Vol. 2 No. 3, pp. 171-188. doi: 10.1108/IJMCE-03-2013-0014

Dreer, B. (2021), "The significance of mentor-mentee relationship quality for student teachers' well-being and flourishing during practical field experiences: a longitudinal analysis", International Journal of Mentoring and Coaching in Education, Vol. 10 No. 1, pp. 101117. doi: 10.1108/IJMCE-07-2020-0041

Gillett-Swan, J. and Grant-Smith, D. (2020), "Addressing mentor wellbeing in practicum placement mentoring relationships in initial teacher education", International Journal of 
Mentoring and Coaching in Education, Vol. 9 No. 4, pp. 393-409. doi: 10.1108/IJMCE-022020-0007

Grant, A.M. (2017), "The third 'generation' of workplace coaching: creating a culture of quality conversations", Coaching: An International Journal of Theory, Research and Practice, Vol. 10. No. 1, pp. 37-53. doi: 10.1080/17521882.2016.1266005

Green, L. S., Norrish, J. M., Vella-Brodrick, D. A. and Grant, A. M. (2013), Enhancing well-being and goal striving in senior high school students: Comparing evidence-based coaching and positive psychology interventions. Available at: https://thepositivityinstitute.com.au/wpcontent/uploads/2017/04/Enhancing-well-being-and-goal-stiving-in-senior-high-schoolstudents.pdf (Accessed 22 August 2021)

Green, L. S., Oades, L. G., and Grant, A. M. (2006), “Cognitive-behavioural, solution focused life coaching: Enhancing goal striving, well-being and hope", Journal of Positive Psychology, Vol. 1 No. 3, 142-149.

Guba, E.G. and Lincoln, Y.S. (1994), "Competing Paradigms in Qualitative Research", in Denzin, N.K. and Lincoln, Y.S. (Eds) Handbook of Qualitative Research, SAGE, Thousand Oaks, Calif.

Hakro, A.N. and Mathew, P. (2020), "Coaching and mentoring in higher education institutions: a case study in Oman", International Journal of Mentoring and Coaching in Education, Vol. 9 No. 3, pp. 307-322. doi: 10.1108/IJMCE-05-2019-0060

Henrick, J., Heine, S. and Norenzayan, A. (2010), "The weirdest people in the world?" Behavioral and Brain Sciences, Vol. 22 Mo. 2-3, pp. 111-135.

Hobson, A. J. (2016), "Judgementoring and how to avert it: Introducing ONSIDE Mentoring for beginning teachers", International Journal of Mentoring and Coaching in Education, Vol. 5 No. 2, pp. 87-110.

Hobson, A.J. (2020), "ONSIDE Mentoring: A Framework for Supporting Professional Learning, Development and Well-Being", in Irby, B.J., Boswell, J.N., Searby, L.J., Kochan, F., Garza, R. and Abdelrahman, N. (Eds.) The Wiley International Handbook of Mentoring: Paradigms, Practices, Programs, and Possibilities, John Wiley \& Sons, Inc., Hoboken, NJ., pp. 521-545.

Hobson, A.J. (2021), "Bringing Mentoring ONSIDE: Averting Judgementoring and Enhancing the Professional Learning, Development and Well-being of Teachers", in Reames, E.H. and Searby, L.J. (Eds) The Art and Science of Mentoring: A Festschrift in Honor of Dr. Frances Kochan, Information Age Publishing, Charlotte, NC., pp. 49-74.

Hobson, A.J., and Maxwell, B. (2020), "Mentoring substructures and superstructures: an extension and reconceptualisation of the architecture for teacher mentoring", Journal of Education for Teaching: International Research and Pedagogy, Vol. 46 No. 2, pp. 184206. 
Hobson, A.J. and McIntyre, J. (2013), "Teacher fabrication as an impediment to professional learning and development: the external mentor antidote", Oxford Review of Education, Vol. 39 No. 3, pp. 345-365.

Hollweck, T. (2019), "I love this stuff!': a Canadian case study of mentor-coach well-being”, International Journal of Mentoring and Coaching in Education, Vol. 8 No. 4, pp. 325-344. doi: 10.1108/IJMCE-02-2019-0036

Jones, M. (2015), "Mentoring and coaching in education practitioners' professional learning: Realising research impact", International Journal of Mentoring and Coaching in Education, Vol. 4 No. 4, pp. 293-302. doi: 10.1108/IJMCE-09-2015-0027

Káplár-Kodácsy, K. and Dorner, H. (2020), "Rebuilding faculty capacities in higher education: An alternative for relational mentoring", Innovations in Education and Teaching International, doi: 10.1080/14703297.2020.1850318

Keddie, A., Mills, M., and Pendergast, D. (2011), "Fabricating an identity in neo-liberal times: Performing schooling as 'number one'", Oxford Review of Education, 37, 75-92.

King, S., van Nieuwerburgh, C., Bolton, L., Al Serkal, A., El Assaad, L., and Mattar, M. (2021), "Exploring the need for an indigenous coaching psychology for the Middle East: A panel discussion at the International Psychology Conference Dubai (IPCD)", The Coaching Psychologist 17(1), 32 -37.

Kochan, F.K. (2013), "Extending the research agenda on mentoring in education", International Journal of Mentoring and Coaching in Education, Vol. 2 No. 3. doi: 10.1108/IJMCE-092013-0049

Kochan, F.K. = Mullen, C.A. (2001), "Collaborative authorship: Reflections on a briar patch of twisted brambles", Teachers College Record, 1-9. Available at: https://www.tcrecord.org/Content.asp?Contentld=10661 (Accessed 22 August 2021)

Kutsyuruba, B. and Godden, L. (2019), "The role of mentoring and coaching as a means of supporting the well-being of educators and students", International Journal of Mentoring and Coaching in Education, Vol. 8 No. 4, pp. 229-234. doi: 10.1108/IJMCE-122019-081

Lofthouse, R. (2020), "Editorial: Why mentors matter", CollectivED 10:2-8, Carnegie School of Education, Leeds Beckett University.

Lucey, C., and van Nieuwerburgh, C. (2020), "'More willing to carry on in the face of adversity': How beginner teachers facing challenging circumstances experience positive psychology coaching. An interpretative phenomenological analysis", Coaching: An International Journal of Theory, Research and Practice, Vol 14 No. 1, pp. 62-77. doi: 10.1080/17521882.2020.1753791

Lunsford, L., Baker, V. and Pifer, M. (2018), "Faculty mentoring faculty: career stages, relationship quality, and job satisfaction", International Journal of Mentoring and Coaching in Education, Vol. 7 No. 2, pp. 139-154. doi: 10.1108/IJMCE-08-2017-0055 
Mena, J., Faikhamta, C. and Clarke, A. (2020), "Mentors' approach to practicum mentoring in the Spanish and Thai contexts: a two-cohort comparison using the Mentoring Profile Inventory", International Journal of Mentoring and Coaching in Education, Vol. 9 No. 2, pp. 169-185. doi:10.1108/IJMCE-08-2019-0079

Mill, J.S. (1962), Utilitarianism, ed. Mary Warnock. Glasgow: William Collins Sons \& Co. (First published 1861.)

Mullen, C.A. (2012), "Mentoring: an overview", in Fletcher, S. and Mullen, C.A. (Eds), Handbook of Mentoring and Coaching in Education, Sage, Thousand Oaks, CA, pp. 7-23.

Mullen, C.A. (2021), "Foreword", in Reames, E.H. and Searby, L.J. (Eds) The Art and Science of Mentoring: A Festschrift in Honor of Dr. Frances Kochan, Information Age Publishing, Charlotte, NC, pp. 3-7.

Ng, A., and Vella-Brodrick, D. A. (2019), "Towards a cross-disciplinary framework for promoting youth wellbeing", International Journal of Wellbeing, Vol. 9 No. 4, pp. 26-42. doi: 10.5502/ijw.v9i4.999

Proctor, C., Tsukayama, E., Wood, A. M., Maltby, J., Eades, J. F., and Linley, P. A. (2011), "Strengths Gym: The Impact of a Character Strengths-Based Intervention on the Life Satisfaction and Well-Being of Adolescents", The Journal of Positive Psychology, Vol. 5 No. 5, pp. 377-388.

Research Excellence Framework (2019), Panel criteria and working methods. Available at: https://www.ref.ac.uk/media/1450/ref-2019 02-panel-criteria-and-workingmethods.pdf (Accessed 22 August 2021)

Rhodes, C. and Fletcher, S. (2013), "Coaching and mentoring for self-efficacious leadership in schools", International Journal of Mentoring and Coaching in Education, Vol. 2 No. 1, pp. 47-63. doi: org/10.1108/20466851311323087

Roche, C. (2019), "Why measuring coaching effectiveness in terms of wellbeing takes practice into the '3rd generation' of coaching. A think piece Working Paper", CollectivED Working Papers, Vol. 8, pp. 78-82.

Sahlberg, P. (2010), "Rethinking accountability in a knowledge society", Journal of Educational Change, Vol. 11, pp. 45-61.

Salavert, R. (2015), "Coaching: An Apprenticeship Approach for the 21st Century", International Journal of Educational Leadership and Management, Vol. 3 No. 1, pp. 4-24. doi: 10.4471/ijelm.2015.02

Salter, T. (2015), "Equality of mentoring and coaching opportunity: making both available to pre-service teachers", International Journal of Mentoring and Coaching in Education, Vol. 4 No. 1, pp. 69-82. doi: 10.1108/IJMCE-08-2014-0031

Short, E., Kinman, G., and Baker, S. (2010), "Evaluating the impact of a peer coaching intervention on well-being among psychology undergraduate students", International Coaching Psychology Review, Vol. 5 No. 1, pp. 27-35. 
Tee Ng, P. (2012), "Mentoring and coaching educators in the Singapore education system", International Journal of Mentoring and Coaching in Education, Vol. 1 No. 1, pp. 24-35. doi: $10.1108 / 20466851211231602$

Tonna, M.A., Bjerkholt, E. and Holland, E. (2017), "Teacher mentoring and the reflective practitioner approach", International Journal of Mentoring and Coaching in Education, Vol. 6 No. 3, pp. 210-227. doi: https://doi.org/10.1108/IJMCE-04-2017-0032

Tschannen-Moran, M. and Carter, C.B. (2016), "Cultivating the emotional intelligence of instructional coaches", International Journal of Mentoring and Coaching in Education, Vol. 5 No. 4, pp. 287-303. doi: 10.1108/IJMCE-02-2016-0008

van Nieuwerburgh, C. (Ed) (2012), Coaching in education: Getting better results for students, educators and parents, Routledge, London.

van Nieuwerburgh, C., Barr, M., Munro, C., Noon, H., and Arifin, D. (2020), "Experiences of aspiring school principals receiving coaching as part of a leadership development programme, International Journal of Mentoring and Coaching, Vol. 9 No. 3, pp. 291-306.

van Nieuwerburgh, C., Knight, J. and Campbell, J. (2019), “Coaching in education”, in English, S. Sabatine, J.M. and Brownell, P. (Eds), Professional coaching: Principles and practice, Springer, pp. 411-426.

van Nieuwerburgh, C. and Oades, L. (2017), "Editorial”, Coaching: An International Journal of Theory, Research and Practice, Vol. 10 No. 2, pp. 99-101.

Waaland, T. (2021), "Job characteristics theory and mentoring: the influence of cognitive tasks and educational leadership on mentoring provided", International Journal of Mentoring and Coaching in Education, Vol. 10 No. 1, pp. 46-66. doi: https://doi.org/10.1108/IJMCE04-2020-0012

Waters, L. (2017), "Progressing Positive Education and Promoting Visible Well-Being in Schools", in Warren, M.A. and Donaldson, S.I. (Eds), Scientific Advances in Positive Psychology, Praeger, Santa Barbara, pp. 229-255.

Whipp, P.R. and Pengelley, R. (2017), “Confidence building through peer observation of teaching and peer coaching in university departments: A good investment for some and not others", International Journal of Mentoring and Coaching in Education, Vol. 6 No. 2, pp. 99-115. doi: 10.1108/IJMCE-07-2016-0059

Wilcoxen, C., Bell, J. and Steiner, A. (2020), "Empowerment through induction: supporting the well-being of beginning teachers", International Journal of Mentoring and Coaching in Education, Vol. 9 No. 1, pp. 52-70. doi: 10.1108/IJMCE-02-2019-0022

Wilson, A. and Huynh, M. (2020), "Mentor-mentee relationships as anchors for pre service teachers' coping on professional placement", International Journal of Mentoring and Coaching in Education, Vol. 9 No. 1, pp. 71-86. doi: doi.org/10.1108/IJMCE-04-2019$\underline{0052}$

Winter, J.S., Bressman, S. and Efron, E.S. (2020), "An innovative model of mentoring teachers in Jewish day schools: A pathway to professional development and teacher well-being", 
International Journal of Mentoring and Coaching in Education, Vol. 9 No. 1, pp. 37-51. doi: 10.1108/IJMCE-02-2019-0009

'This number excludes Editorials, Guest Editorials and Commentary papers. 